\title{
PROBLEMY, DOŚWIADCZENIA I METODY GROMADZENIA KSIĘGOZBIORU *
}

Polskie książki i czasopisma gromadzone są w Bibliotece Uniwersyteckiej KUL poprzez dary, gratisy, kupno i wymiane krajowa. W tym wystąpieniu chcialbym sie zając problematyka zakupu.

Kupno polskich publikacji stanowi prawie polowe wszystkich wplywów do Biblioteki. Obecnie bibliotekarz ma możliwośc dotarcia do wielu źródeł informujacych o publikacjach polskich. Wykladane sa w ksiegarniach, można je zebrać na targach książki czy zwracając się bezpośrednio do wydawców. Różnorodnosć jest tu wielka. Podstawowy material w tej dziedzinie to "Przewodnik Bibliograficzny", ale sa też oferty ksiegarskie, materialy instytucji wydawniczych, takie jak zapowiedzi wydawnicze poszczególnych firm, doraźne anonse, katalogi składowe, zestawienia retrospektywne. Pomocne moga być także notki w. czasopismach, czy też informacje czytelników.

Mimo wszystko brak jest jednak pełnej informacji o ukazujacych się publikacjach. „Przewodnik Bibliograficzny” rejestruje tylko to, co dociera do Biblioteki Narodowej (podobno ok. $70 \%$ produkcji wydawniczej) i to z dużym opóźnieniem w stosunku do czasu ukazania się książki. Informacje o książkach majacych sie ukazać sa wyrywkowe i niepelne (nie ma „Zapowiedzi Wydawniczych" publikowanych przez Składnice Ksieggarska). Opisy robione są nieraz niedokładnie, np. same tytuły bez podania nazwisk autorów, często bez adnotacji o treści książki. To jest kłopot jednego rodzaju w gromadzeniu książek.

Drugi - to sprawa wydawnictw. Wiele $z$ nich upadło a poszukujemy jeszcze książek prżez nie wydanych. Powstają i publikują książki liczne nowe wydawnictwa. Niestety, czessto nie można do nich dotrzeć $\mathrm{z}$ powodu braku adresu lub z powodu krótkiego istnienia oficyny, gdy po wydaniu kilku tytulow wydawnictwo konezy żywot.

Trzeci problem to ksiegarnie. Dawne, duże, państwowe sa zamykane lub zawężaja swoja oferte handlowa. Nowe czessto nie sprowadzaja szerszej gamy

\footnotetext{
*Piśmiennictwo polskie opracował Wiktor Kapłan, natomiast piśmiennictwo obce Elżbieta Żelechowska.
} 
wydawnictw naukowych, bo im się to nie opłaca (zbyt duże ryzyko niesprzedania) lub hurtownikowi czy wydawcy nie oplaca sie wysyłac małej ilosci egzemplarzy.

W tej sytuacji w Bibliotece KUL przyjęto trzy podstawowe formy zakupu książek:

1. zakup w ksiegarniach,

2. zamawianie u wydawców,

3. zakup od osób prywatnych.

Prowadzimy stały przegląd nowości wydawniczych w kilku ksiegarniach lubelskich, tj. w jednej dużej Domu Książki, w ORPAN-ie, w kilku prywatnych i w Kurii Archidiecezjalnej oraz w księgarniach warszawskich (naukowej im. Prusa, sw. Jana, Soli Deo i innych).

W większości wypadków w księgarniach na oddzielną półkę odkładane są ostatnie nowości dla nas. Dokonujemy przeglądu książek na miejscu. Za odebrane płacimy kaucje i przywozimy do Biblioteki, gdzie sprawdzamy w katalogu alfabetycznym. Następnie odwozimy do ksiegarni $z$ podziałem na książki przeznaczone do zakupu $\mathrm{i}$ do zwrotu. W koncu zakupione zabieramy $\mathrm{z}$ rachunkiem do Biblioteki, gdzie po wpisaniu proweniencji przekazujemy do opracowania. Księgarnie warszawskie wystawiaja od razu po pierwszym przeglądzie rachunek, a książki, które okazaly się dubletami zwracamy przy następnej bytnosci.

Trzeba tu, szczególnie przy wyjazdach, trochę intuicji czy bibliotekarskiej pamiecci. Oczywiście nieodzowna jest gotówka do dyspozycji i środek transportu. Procedura ta jest dośc prosta, zakłada częsciowo obopólne zaufanie zainteresowanych stron. Korzyści są duże - ksiegarnia ma okazję sprzedać maksymalną ilośc książek, pracownicy biblioteki zaś oszczędzaja mnóstwo czasu, który straciliby na spisywanie książek w księgarni i dopiero późniejsze sprawdzanie tych informacji na miejscu. Metode te stosowalismy poczatkowo w kontaktach z Kuria Biskupia rozszerzając ją w zmienionej sytuacji rynkowej na ksiegarnie. Duże księgarnie są bardziej otwarte na takie propozycje. Latwiej również do tego przekonać ksiegarzy przy stalym zakupie większej ilości książek.

Tych publikacji, których nie można znaleźć w ksiegarniach, trzeba szukać bezposrednio u wydawców. Chodzi głównie o wydawców nieprofesjonalnych, ale nie tylko. Wiele ksiazzek wydanych w dużych, profesjonalnych wydawnictwach nie dociera do ksiegarn. W tej sytuacji korzystamy $z$ "Przewodnika Biblio? graficznego" oraz informatorów wydawniczych i ksiegarskich ze szczególnym uwzgleednieniem wszelkich zapowiedzi.

Proces zamawiania jest dosć dlugi. Najpierw typowanie poszczególnych pozycji, potem sprawdzanie $w$ katalogu alfabetycznym, wycinanie tytulów i naklejanie, czyli sporządzanie fiszek zamówieniowych, następnie podział na firmy wydawnicze, szukanie adresów firm i zamawianie korespondencyjne książek lub kwerenda w księgarniach (w zależności od wydawnictwa). W końcu fiszki zamówionych publikacji trzeba wlączyć do kartoteki zamówień. Plusem tej formy 
poszukiwań książek jest fakt, iż w wielu wypadkach otrzymujemy książki w darze, bez rachunku. Niestety, większosc publikacji, o które prosimy pisemnie jest wyczerpana. Często też nie otrzymujemy żadnej odpowiedzi na nasze pisma.

Najkłopotliwsze w tym wszystkim okazuje sie ustalenie adresu wydawcy. Wielu nowych firm nie ma w żadnych informatorach, niemniej należy zwrócić uwage na wielka przydatnośc $w$ tym względzie katalogów Krajowych i Międzynarodowych Targów Książki oraz wydanego przéz Składnice Ksiegarską "Katalogu firm wydawniczych 1992" $\mathrm{z}$ adresami ok. 1300 firm.

Przy szukaniu adresów stowarzyszen regionalnych, towarzystw naukowych, kulturalnych, urzed $6 \mathrm{w}$, instytucji naukowych, muzeow, bibliotek itp. nieodzowny jest podręczny zbiór informatorów adresowych. Niestety, ostatnio wiele instytucji i towarzystw zmienilo adresy i informacje moga byc nieaktualne, ale czéściowo może slużyć pomoca kartoteka adresowa. Nanosi się w niej wszelkie zmiany w oparciu o adresy nadawców przesyłek zamówionych książek, często nowe adresy wydawców czy autorów przysylających dary. W naszej Bibliotece włączamy tam też adresy nowych firm wzięte $\mathrm{z}$ zakupionych książek.

Należałoby podkreślić jeszcze rolę targów książki (miedzynarodowych i krajowych) w zdobywaniu polskiej książki. Przy okazji bezpośrednich kontaktów $\mathrm{z}$ wydawcami można złożyć pisma zamówieniowe, kupić nowości po cenach promocyjnych, szczególnie takich firm, których publikacji w ksiegarniach nie można spotkać. W czasie rozmów udaje się czasem załatwić egzemplarze gratisowe. W 1992 r. zrealizowalismy na targach sporą ilosc zamówień z ostatnich kilku lat.

Biblioteka nasza ma możliwość zakupu książek od osób prywatnych bez pośrednictwa antykwariatu. Książki wyceniamy na miejscu, w szczególnych przypadkach konsultujemy się $z$ antykwariuszem. Jednak te formę zakupu bardzo ograniczamy, ponieważ sprawdzanie ofert prywatnych zajmuje zbyt dużo czasu w stosunku do efektów (wyłonienia tych tytułów, które ewentualnie kupilibysmy). Dotyczy to zwykle przecież publikacji starszych, w które Biblioteka nasza jest dosc dobrze zaopatrzona.

Bywają nieraz sytuacje, kiedy można kupić potrzebną książkę bez możliwości otrzymania rachunku. Sa to zwykle jakies male punkty sprzedaży, kioski itp. A książek tam rozprowadzanych czesto nie ma w ksiegarniach. Wtedy zamiast rachunku sporządzamy protokól, który podpisują następnie trzy osoby. Jest to duże ułatwienie w pracy akcesyjnej.

Poważnym problemem gromadzenia zbiorów jest niedbalstwo w procesie wytwarzania książki. W ostatnim okresie bardzo zwiększyła się ilośc defektów. Najlepiej jest dokładnie przeglądać książki przy zakupie. Jeśli defekt zostanie zauważony później, nawet w książce już opieczętowanej, są dwie możliwości: wymiana na inny egzemplarz lub zwrot kosztów. Ksiażki zakupione w ksiegarniach Domu Książki moga byế wymienione w ciagu roku od daty zakupu 
w dowolnej ksiegarni tego przedsiebbiorstwa. Prywatne ksiegarnie natomiast przyjmuja do wymiany tylko egzemplarze rozprowadzane przez siebie.

Publikacje wartościowsze nie leżą zbyt długo na półkach księgarskich. Czesto $w$ chwili zauważenia defektu są już wyczerpane. Wtedy nie warto zwracać książki za ekwiwalent pieniężny. Szukamy identycznej książki w innej bibliotece, wykonujemy odbitki kserograficzne zdefektowanych stron i uzupelniamy nasz egzemplarz zachowując $w$ ten sposób konkretny tytuł dla czytelnika.

Powyższe uwagi w glównej mierze dotyczyły druków zwartych. Trochę innym problemem, który chcę tylko pokrótce poruszyć, jest gromadzenie/czasopism.

W roku akademickim 1991/92 na 1423 tytuły gromadzonych na bieżąco czasopism krajowych było:
$z$ prenumeraty -601
z zakupu -139
$\mathrm{z}$ darów $\quad-388$
z wymiany -295

Prenumerata to glównie „Ruch" (ciagle zmniejszajaca się oferta), ORPAN i poszczególne wydawnictwa. Zakupu dokonujemy w ksiegarniach, kioskach i od osób prywatnych.

Informacje o nowych tytułach zdobywa sie z „Bibliografii Wydawnictw Ciagłych Nowych, Zawieszonych i Zmieniajacych Tytul” (dodatek do „Przewodnika Bibliograficznego"). Niestety, są tu spore opóźnienia. Czasopismo może już się nie ukazywać $w$ chwili drukowania o nim danych (chodzi o krótkotrwale edycje). Dodatkowym źródłem informacji może być cennik „Ruchu” a także anonsy w prasie oraz nowe tytuly zauważone w ksiegarniach czy kioskach.

W gromadzeniu czasopism borykamy się z różnymi trudnosciami. Ciagle zmieniające się ceny pociagają za soba krótkie okresy prenumeraty czasopism (kwartalne, pólroczne). Zmusza to do stalego przeglądania kartotek i „pilnowania" terminów. Wiele czasopism naukowych ukazuje się $\mathrm{z}$ poważnym opóźnieniem - są kłopoty $z$ ustaleniem, czy jeszcze dany tytuł jest wydawany. Jest coraz więcej czasopism komercyjnych. Wynikają $z$ tego problemy z selekcja.

Ogólnie sytuacja na rynku wydawniczo-księgarskim w zdobywaniu książki czy szybkiej i możliwie pelnej informacji a jednocześnie wielość firm wydawniczych i zwiększająca sie stale produkcja wydawnicza wskazuja na koniecznosc powieksszania szczupłego personelu Działu Gromadzenia, aby uniknąć narastania zaległości, a przez to utraty publikacji, których nie zdąży się nabyć. Pewną nadzieje na poprawe sytuacji może budzić rozpoczynająca się komputeryzacja Biblioteki KUL. Sprawne i efektywne funkcjonowanie procesu gromadzenia w oparciu o komputery, zważywszy na wiele okolicznosci, wydaje się jednak sprawą dość odlegla. 
Piśmiennictwo obce zamawiane jest właściwie w dwóch Sekcjach Oddziału Gromadzenia:

- w Wymianie Zagranicznej

- przez Referat zakupu książek obcych Sekcji Akcesji, Kupna, Darów i Gratisow.

O polityce gromadzenia mówiliśmy już wcześniej. Zajmijmy się więc Referatem zakupu książek obcych. Na wstępie krótka charakterystyka czynności wykonywanych:

1) zamawianie w oparciu o katalogi wydawnicze nowości lub oferty przysyłane przez dystrybutorów książek zagranicznych w Polsce,

2) typowanie pozycji do ewentualnego zakupu i sprawdzanie ze stanem katalogu alfabetycznego Biblioteki oraz ze stanem kartoteki zamówien,

3) sporządzanie fiszek zamówieniowych oraz zamawianie,

4) włączanie kopii fiszek zamówionych publikacji do kartoteki zamówień,

5) weryfikacja otrzymanych książek z kartoteką zamówień i ich selekcja,

6) reklamacje,

7) aktualizacja kartotek (dezyderatów i zamówień),

8) cotygodniowa wystawa nowości zagranicznych,

9) sporządzanie spisów (otrzymanych w darze od ofiarodawców zagranicznych) ksiegozbiorów i wpisywanie proweniencji oraz sprawdzanie w katalogu alfabetycznym,

10) selekcja i segregacja zakupów i darów oraz książek i czasopism przekazywanych do dalszego opracowania,

11) szkolenie studentów i praktykantów,

Wydawnictwa zamawiamy w oparciu o katalogi wydawnicze nowości lub oferty przysyłane przez dystrybutorów ksiazżek obcych w Polsce (np. Ośrodek Rozpowszechniania Wydawnictw Naukowych Polskiej Akademii Nauk, Skladnica Księgarska, International Publishing Service i inne).

$\mathrm{Z}$ wydawnictw niemieckich, jak Walter de Gruyter, Wissenschaftliche Buchgesellschaft, francuskich (Presses Univ. de France, Gallimard, Seuil) czy też anglojezycznych (Cambridge Univ. Press, Blackwell, Oxford Univ. Press, California Univ. Press, Yale Univ. Press) i innych typujemy pozycje do ewentualnego zakupu i sprawdzamy ze stanem katalogu glównego Biblioteki oraz ze stanem kartoteki zamówien.

Po segregacji (tzn. decyzji, gdzie należy zlożyć dezyderaty) i oddzieleniu dezyderatek zamawianych za pośrednictwem wymiany na pozostale sporządzane są fiszki zamówieniowe, które wraz z listami wedrują do posredników (ORPAN, IPS). Następnie kopie wszystkich fiszek, zarówno przez zakup, jak i przez wymianę zamówionych książek umieszczamy (wlączamy) w kartotece zamówień.

Warunkiem otrzymania zamawianych publikacji jest uiszczenie przedplat wymaganych przez wydawców (nie wszystkich). Należnosć za otrzymane książki i czasopisma należy zapłacić w ciagu kilku dni od chwili otrzymania rachunku 
gotówką lub przelewem. Bardziej korzystny jest zakup książki obcej na Targach Książki (np. na ostatnich Międzynarodowych Targach Książki w Warszawie cena eksponatu była niższa ok. 20\%).

W latach ubiegłych Biblioteka nasza miała, ze względów finansewych, niewielkie możliwości zakupu, zawsze drogiej, ale nie zawsze dostepnej na rynku, literatury naukowej obcej. W ostatnich latach sytuacja zmienila się. Naukowa i teologiczna książka obca jest dostępna, jak również fundusze przeznaczone na zakup książki obcojęzycznej sa o wiele większe. Dlatego też w minionym roku akademickim mogliśmy zakupić ponad 34 tys. woluminów książek $\mathrm{i}$ czasopism nowych, w tym około 5 tys. druków zwartych oraz 392 tytuly czasopism (prenumerata - 362 tytuły) zagranicznych za niebagatelną sumę około 2,5 mld. zł.

Otrzymany $w$ ten sposób egzemplarz weryfikujemy $z$ nasza kartoteka zamówień (tzn. wyłączamy fiszkę) a książkę zaopatrujemy w proweniencje i kierujemy do dalszego opracowania w Sekcji Opracowania Tymczasowego, lub jeżeli jest czasopismem, przekazujemy do Dzialu Czasopism.

Do obowiązków referatu należą również wszelkiego rodzaju reklamacje związane $\mathrm{z}$ zakupem zarówno druków zwartych, jak i czasopism (oprócz prenumeraty).

Przynajmniej raz na rok obie kartoteki (dezyderatów i zamówień) są aktualizowane.

Podobnie postępujemy przy zamawianiu książki obcej droga wymiany zagranicznej $\mathrm{z}$ tym, że rozliczamy sie albo naszymi wydawnictwami albo wykorzystujemy dary pieniężne przeznaczone dla naszej Biblioteki (np. Towarzystwo Przyjaciól Katolickiego Uniwersytetu Lubelskiego w Londynie, Fundacja Rektorów w Niemczech). Kopie tych zamówień również umieszczamy w kartotece zamówien.

Zobaczmy, jak wygląda ilościowo zakup i zamówienia książki obcej w roku akademickim 1991/92. Na zamówione 8671 tytułów zwartych i czasopism, 395 tytułow to serie wydawnicze (268 - tytuły serii zamawianych przez wymiane zagraniczną), 392 tytuły - to czasopisma. Do realizacji pozostało 875 zamówień książkowych. Z zakupu otrzymalismy 4669 woluminów a z wymiany 2340 woluminów książek i czasopism.

$\mathrm{Z}$ otrzymanych nowości druków zwartych i ciaglych przygotowujemy cotygodniowa wystawe.

Do obowiązków Referatu należą również:

- sporządzanie spisów księgozbiorów otrzymanych w darze od ofiarodawców zagranicznych $i$ wpisywanie proweniencji oraz sprawdzanie $w$ katalogu alfabetycznym,

- selekcja i segregacja zakupów i darów oraz książek i czasopism przekazywanych do zbiorów. 